\title{
HEAD LICE IN SCHOOL CHILDREN IN UBERLANDIA, MINAS GERAIS STATE, BRAZIL
}

\author{
Gabriela G. Mendes ${ }^{1}$, Raquel Borges-Moroni ${ }^{2}$, Fábio T. Moroni ${ }^{3}$ and Júlio \\ Mendes $^{2}$
}

\section{ABSTRACT}

School-aged children have shown to be the group most susceptible to Pediculus capitis infestation, possibly due to their habits and behaviors. The purpose of the study was to verify the prevalence of head pediculosis in preschool children from Uberlândia, MG, and factors associated with infestation. The children's parents or guardians were also evaluated regarding socioeconomic status, knowledge of symptomatology and control of this ectoparasitosis. Data were obtained by direct examination of each child's head and a questionnaire answered by parents/guardians. The overall prevalence rate was $7.5 \%$ among the 372 children examined, and 4 to 5 -year-old girls with long hair presented significantly higher prevalence rates. Information from the questionnaires indicated that $45 \%$ of the children had already been infested at least once and the main symptom mentioned was intense itching on the scalp. Those responsible mostly used natural control measures to control infestations. The results indicated that children under the age of six should also be included in head pediculosis control programs.

KEY WORDS: Head lice; children; epidemiology; central Brazil.

\section{INTRODUCTION}

Pediculus capitis De Geer(Phthiraptera: Pediculidae) is an hematophagous ectoparasite of the human scalp (Triplehorn \& Jonnson, 2011). Human head lice infestation is characterized by intense pruritus, irritation at the affected site and secondary infections. High infestations can lead to anemia when associated with poor nutrition. Transmission occurs mainly through contact between people and indirectly, through sharing fomites, such as combs, brushes and caps (Linardi \& Barbosa, 2016). Infestations occur more frequently in people with precarious hygiene, low socioeconomic status and who spend much of their time in social environments (Mirza \& Shamsi, 2010). Schoolchildren aged six to thirteen are the most affected (Linardi \& Barbosa, 2016).

\footnotetext{
1. Discente, Ciências Biológicas, Instituto de Biologia, Universidade Federal de Uberlândia (UFU), Uberlândia, MG, Brazil.

2. Instituto de Ciências Biomédicas, UFU, Uberlândia, MG, Brazil.

3. Faculdade de Medicina, UFU, Uberlândia, MG, Brazil.
}

Address for correspondence: Raquel Borges Moroni. ICBIM/UFU. Av. Amazonas, s/n, bloco 4C. Bairro Umuarama, CEP 38408100, Uberlândia, MG, Brazil. E-mail: borgesraquel@hotmail.com 
Considering the size of Brazil, studies on head pediculosis in the country are scarce, most are locally focused and generally follow an epidemiological approach. Linardi et al. (1988) verified an overall prevalence of 5 to $6 \%$ when examining samples of cut hair from barbershops, in Belo Horizonte, Minas Gerais, however, these same authors (1989) found a prevalence of 10,2\%, exclusively in students in the public network of the same city. In the same state, studies in Uberlandia registered prevalence rates between $7.4 \%$ and $35 \%$ (Borges \& Mendes, 2002, Borges et al., 2007). In Londrina, Paraná, Gabani et al. (2010) observed that $28 \%$ of the children showed signs of infestation and active pediculosis. In Manaus, Amazonas state, prevalence rates of $18.5 \%$ (Borges-Moroni et al., 2011) and 44.8\% (Amazonas et al., 2015) were recorded in children and adolescents, while in Fortaleza, Ceará, Heukelbach et al. (2003) noticed a prevalence of $43.3 \%$ in groups with low socioeconomic status.

Hence, pediculosis persists as an important public health problem in Brazil and certain population groups show high rates of infestation, indicating that obtaining up-to-date information on this ectoparasitosis is important. Information on the most affected population groups and factors associated with infestation is essential for the formulation and implementation of measures for its control (Borges-Moroni et al., 2011, Nunes et al., 2014).

Spending time in the social environment of schools is one of the factors responsible for the increased prevalence of pediculosis in children between six and thirteen years of age (Linardi et al., 1989, Linardi \& Barbosa, 2016). On the other hand, Brazil has seen an increase in the number of children aged zero to five attending preschools or preschool classes in schools (MEC, 2014). Considering that spending time in the social environment within these institutions could be a factor contributing to the occurrence of lice in children, it is necessary to include this age group in studies on head pediculosis.

The purpose of this study was to verify the prevalence of head pediculosis in preschool children up to five years of age in the city of Uberlândia, Minas Gerais state, analyze its association with other factors, including sex, age, ethnicity, hair characteristics and the socioeconomic profiles the children, and ascertain the level of knowledge concerning pediculosis among parents or guardians.

\section{MATERIAL AND METHODS}

The study was conducted in eight public infant education institutions in the urban region of Uberlândia, Minas Gerais, from September to November 2014. These preschools cater for children between zero and five years of age. They were selected based on the $0-5$ years of age criteria and location within the urban area of the metropolitan region. Children from four preschools located in the central region and four others on the outskirts of the city were examined. 
Diagnosis for head lice, including eggs, nymphs and adults was made by direct inspection of the children's heads, as described by Nunes et al. (2015). Individuals who presented eggs, nymphs or adults were considered positive. The examinations were performed by a previously trained person (Borges \& Mendes, 2002).

The children were grouped as follows: sex; age - 0 to 1 year old, 2 to 3 years old and 4 to 5 years old; hair length - short: $<3 \mathrm{~cm}$ in length, medium: 3 to $10 \mathrm{~cm}$, and long: $>10 \mathrm{~cm}$; hair color - dark: black and brown, light: blond and red; hair type - curly, wavy or straight; and ethnicity - Black: black and mulatto, and non-Black: pardo and white; according to the methodology described by Borges et al. (2007).

Parents and guardians were asked to complete a questionnaire that addressed issues of prevention, symptomatology, the control of pediculosis and their socioeconomic profiles. They were divided into three groups, according to income, from 1 to 3 minimum wages, 4 to 6 minimum wages, and 7 or more minimum wages. This information was used to draw inferences regarding the socioeconomic profile of the children.

Comparisons between two or more proportions were made using the $\chi^{2}$ test. In cases where significant differences were observed between more than two proportions, the data were preliminarily submitted to angular sine transformation ( $\mathrm{p}^{\prime}=$ arc. Sine $\left.\sqrt{ } \mathrm{p}^{\prime}\right)$ and then compared by the Tukey test (Zar, 1999). A significance level of 5\% was adopted for all tests. Confidence intervals $(95 \%)$ were calculated for the prevalence rates and prevalence ratios determined.

The study was started after the parents or guardians had signed a term of free informed consent and the research was approved by the Research Ethics Committee of the Federal University of Uberlândia, under protocol no. CAAE: 32677414.6.0000.5152.

\section{RESULTS AND DISCUSSION}

Among the 372 children examined for head pediculosis, the overall prevalence rate was $7.5 \%$. The number of children examined in two of the eight preschools, one in the central region and the other on the outskirts of the city (preschools I and VII), was small (Table 1) because the parents or guardians did not consent to the examinations. The prevalence rates obtained for schools in the central region and outskirts of the city were $7.2 \%$ and $8.3 \%$, respectively, and did not differ statistically $\left(\chi_{0.05(1)}=0.1402\right)$. Comparing the rates verified for each school, regardless of their location in the city, differences between the prevalence rates were observed $\left(\chi_{0.05(5)}^{2}=25.1874\right.$; $\mathrm{p}<0.005$ ) (Table 1). In particular, the prevalence rates observed for the two preschools that lacked an adequate number of participants (preschools I and VII) were not compared with those of the remaining schools. The two highest 
prevalence rates observed (preschools V and III) were significantly different from the two lowest rates included in the comparison (preschools VI and II) $(\mathrm{P}<0.05)$. It is worth highlighting that the families of the children attending preschools located in the central districts of the city present a heterogeneous socioeconomic profile, whereas those from neighborhoods on the outskirts of the city had a lower socioeconomic status (Table 1). The socioeconomic profile of the children's families seems to be associated with the fact that placement in these preschools is free, a finding also observed by Borges \& Mendes (2002) in a study conducted in the same city involving children of several age groups attending public schools.

Table 1. Relation between head pediculosis and the location of urban public preschools and the socioeconomic profiles of parents or guardians in Uberlândia, Minas Gerais state, Brazil.

\begin{tabular}{lccr}
\hline Preschool & $\begin{array}{c}\text { Socioeconomic } \\
\text { profile }\end{array}$ & $\begin{array}{c}\text { Children } \\
\text { examined (n) }\end{array}$ & Prevalence rate (\%) \\
\hline I & - & 8 & 0 \\
II & G1, G2, G3 & 80 & 1.2 \\
III & G1, G2, G3 & 115 & 13.9 \\
IV & G1, G2, G3 & 48 & 2.1 \\
CR Total & G1, G2, G3 & 251 & $7.2(4.0-10.4) \mathrm{A}$ \\
V & G1 & 44 & 18.2 \\
VI & G1 & 46 & 0 \\
VII & G1 & 8 & 0 \\
VIII & G1 & 23 & 8.7 \\
OC Total & G1 & 121 & $8.3(3.4-13.2) \mathrm{A}$ \\
Overall Total & & 372 & 7.5 \\
\hline
\end{tabular}

A: prevalence rates with the same letter are not statistically different at a 5\% level of significance. CR, I to IV: schools located in the central region. OC, V to VIII: schools located on the outskirts of the city. G1: 1 to 3 minimum wages; G2: 4 to 6 minimum wages; G3: 7 or more minimum wages. (-) did not respond to the questionnaire.

In the urban and rural regions of the same city, Borges \& Mendes (2002) found an overall prevalence rate of $35 \%$. The discrepancy in the values between these two studies could be because the former mainly involved children aged 6 to 15 years, the age group most commonly affected by this ectoparasitosis (Linardi \& Barbosa, 2016). It also seems reasonable to assume that some improvement in the control of head pediculosis within families and educational institutions has occurred over the intervening period in 
Uberlândia. The frequent application of and improvement in control measures tend to reduce the prevalence of this ectoparasitosis (Heukelbach et al., 2008). Another study among the elderly in institutional homes in Uberlândia showed a prevalence rate of $5.5 \%$ for this pediculosis (Borges et al., 2007). According to these authors the low prevalence verified in this group was because these institutions had adopted control measures against lice.

It is important to stress that head pediculosis has presented a high prevalence in Brazil and in other countries (Linardi et al., 1989; Speare \& Buettner, 1999., Courtiade et al., 1993, Heukelbach et al., 2003, Gabani et al., 2010; Borges-Moroni et al., 2011; Gutiérrez et al., 2012, Raheem et al., 2014; Amazonas et al., 2015). The differences in these reported occurrence rates show that different population groups present different epidemiological profiles, with different degrees of exposure to ectoparasitosis. This further demonstrates the importance of these studies, in order to provide updated epidemiological records to the relevant authorities of each locality or region.

The higher prevalence among girls $(13 \%)\left(\chi_{0.05(1)}^{2}=15.7056 ; \mathrm{p}<0.005\right)$ (Table 2), is in agreement with several prior studies in Brazil and other countries (Linardi et al., 1989; Barbosa \& Pinto, 2002; Kokturk et al., 2003; Counahan et al., 2004; Nazari \& Saidijan, 2007; Borges-Moroni et al., 2011; Amazonas et al., 2015). This higher prevalence could be due to the fact that girls and women wear their hair long more frequently. The influence of hair length on the prevalence of pediculosis showed a higher rate among children with long hair $(16 \%)\left(\chi_{0.05(1)}^{2}\right.$ $=16.7473 ; \mathrm{p}<0.005)($ Table 3$)$, thus corroborating the studies of several authors (Chunge, 1986; Linardi et al., 1989; Cazorla et al., 2007; Borges et al., 2011). Long hair provides a larger contact surface, is generally more difficult to care for and can hinder early diagnosis. Together, these factors increase the likelihood of ectoparasite infestation and transmission in this group (Linardi et al., 1989, Heukelbach et al., 2003, Toloza et al., 2009).

A significant increase in prevalence rates was observed as the child's age increased. Four and five year old children were more affected than younger children $\left(\chi_{0.005(2)}^{2}=7.3499 ; \mathrm{p}<0.05\right)$ (Table 2). A similar age group (3-6 years old) was studied in Argentina and the prevalence rate of $42.7 \%$ was verified (Gutiérrez et al., 2012). Children of this age show greater autonomy than younger children and more readily participate in group activities, furthering the transmission of pediculosis through direct contact (Reinhard \& Buikstra, 2003, Catalá et al., 2005, Cazorla et al., 2007).

Of the 700 questionnaires distributed among parents and guardians of the children attending these eight preschools, only 370 (52.8\%) were returned. Analysis of the association between pediculosis and income was based on 296 responses (80\%). Within the first income group (1-3 minimum wages), $45.2 \%$ of the children had been infested with lice at some point in their lives. A decrease of $28.9 \%$ and $29.1 \%$, respectively, was observed for the other two groups (4-6 and 7 or more minimum wages). Some authors have verified that 
lice infestation occurs with greater frequency in the lowest socioeconomic class (Linardi et al., 1988, 1995). Low socioeconomic status seems to be a limiting factor among parents and guardians for achieving adequate control of pediculosis in children (Piquero-Casals et al., 2004, Kamiabi \& Nakhaei, 2005, Akhter et al., 2010). However, other authors have not reported any association between pediculosis and the socioeconomic profile (Chouela et al., 1997, Saddozai \& Kakarsulemankhel, 2008).

Table 2. Prevalence of head pediculosis in children attending urban public preschools in Uberlândia, Minas Gerais state, Brazil, according to sex, ethnicity and age group.

\begin{tabular}{lcccc}
\hline & $\begin{array}{c}\text { Children } \\
\text { examined } \\
(\mathrm{n})\end{array}$ & $\begin{array}{c}\text { Children } \\
\text { infested } \\
(\mathrm{n})\end{array}$ & $\begin{array}{c}\text { Prevalence } \\
\text { rate } \\
(\%)(95 \% \mathrm{CI})\end{array}$ & $\begin{array}{c}\text { Prevalence } \\
\text { ratio } \\
(\%)(95 \% \mathrm{CI})\end{array}$ \\
\hline Sex & & & & \\
Male & 187 & 4 & $2.1(0.1-4.2) \mathrm{A}^{\mathrm{a}}$ & - \\
Female & 185 & 24 & $13.0(8.1-17.9) \mathrm{B}$ & $6.1(2.1-17.2)$ \\
Ethnicity & & & & \\
Non-Black & 297 & 22 & $7.4(4.4-10.4) \mathrm{A}$ & - \\
Black & 75 & 6 & $8.0(1.9-14.1) \mathrm{A}$ & $1.1(0.4-2.6)$ \\
Age group & & & & 0 \\
0-1 year old & 22 & 0 & & \\
2-3 years old & 118 & 4 & $3.4(0.1-6.6) \mathrm{A}$ & - \\
4-5 years old & 232 & 24 & $10.3(6.4-14.2) \mathrm{B}$ & $3.0(1.1-8.6)$ \\
\hline
\end{tabular}

A: prevalence rates with the same letter are not statistically different at a $5 \%$ level of significance. B and ${ }^{\text {a: }}$ prevalence rates with different letters are statistically different from each other at a $5 \%$ level of significance. $* 95 \% \mathrm{CI}, 95 \%$ confidence interval.

The answers provided in the 370 questionnaires regarding prevention, symptomatology and control of head pediculosis indicated that most children washed their hair every day (58.4\%), suggesting that infestation depends on factors other than hygiene (Catalá et al. 2005, Borges-Moroni et al., 2015). Regarding the frequency of infestations mentioned by parents and guardians, $42.7 \%$ responded that their children had suffered an infestation, indicating that head pediculosis is more common in this population than the prevalence rate estimated by head examinations might suggest. The control methods mentioned were the use of a fine comb (40.4\%), manual removal (29.8\%) and the use of topical pediculicides (12.4\%), as efficiently used by Pagotti et al. 
(2012) for the control of this pediculosis. However, the results obtained in the head examinations and based on the responses in the questionnaires indicate that despite the use of apparently adequate control methods and the existence of control programs in these preschools, head pediculosis is still frequent in children in Uberlândia.

Table 3. Prevalence of head pediculosis in children attending urban public preschools in Uberlândia, Minas Gerais state, Brazil, according to hair characteristics.

\begin{tabular}{|c|c|c|c|c|}
\hline $\begin{array}{c}\text { Hair } \\
\text { characteristics }\end{array}$ & $\begin{array}{l}\text { Children } \\
\text { examined } \\
\text { (n) }\end{array}$ & $\begin{array}{c}\text { Children } \\
\text { infested } \\
\text { (n) }\end{array}$ & $\begin{array}{l}\text { Prevalence } \\
\text { rates } \\
(\%)(95 \% \mathrm{CI})\end{array}$ & $\begin{array}{l}\text { Prevalence } \\
\text { ratio } \\
(\%)(95 \% \mathrm{CI})\end{array}$ \\
\hline \multicolumn{5}{|l|}{ Length } \\
\hline Short: $<3 \mathrm{~cm}$ & 197 & 6 & $3.0(2.9-3.2) \mathrm{A}^{\mathrm{a}}$ & - \\
\hline Medium: & 69 & 5 & $7.2(1.1-13.3) \mathrm{AB}$ & $2.4(0.7-7.5)$ \\
\hline \multicolumn{5}{|l|}{$3-10 \mathrm{~cm}$} \\
\hline Long: $>10 \mathrm{~cm}$ & 106 & 17 & $16.0(9-23) \mathrm{B}$ & $5.3(2.1-13)$ \\
\hline \multicolumn{5}{|l|}{ Type } \\
\hline Curly & 54 & 2 & $3.7(0-8.7) \mathrm{A}$ & - \\
\hline Wavy & 110 & 7 & $6.4(1.8-10.9) \mathrm{A}$ & $1.7(0.4-8)$ \\
\hline Straight & 208 & 19 & $9.1(5.2-13) \mathrm{A}$ & $2.5(0.6-10.2)$ \\
\hline \multicolumn{5}{|l|}{ Color } \\
\hline Dark & 286 & 19 & $6.6(3.8-9.5) \mathrm{A}$ & - \\
\hline Light & 86 & 9 & $10.5(4-16.9) \mathrm{A}$ & $1.6(0.7-3.3)$ \\
\hline
\end{tabular}

A: prevalence rates with the same letter are not statistically different at a $5 \%$ level of significance. B and ${ }^{\text {a: }}$ prevalence rates with different letters are statistically different from each other at a $5 \%$ level of significance. $* 95 \% \mathrm{CI}, 95 \%$ confidence interval.

The main epidemiological aspects associated with head pediculosis are relatively well known. However, their degree of importance varies according to the profile of the population groups present in a given population and/or region. Spending time in social environments is one of the most important factors for the occurrence of this ectoparasitosis. In Brazil, children have started attending preschools or kindergartens at an earlier age in recent years. Among these children, age groups that present greater autonomy and capacity for socialization are more susceptible to this ectoparasitosis. 


\section{ACKNOWLEGEMENTS}

The authors would like to thank the staffs at the preschools surveyed and the parents and guardians for authorizing the participation of the children in this study.

\section{REFERENCES}

1. Akhter S, Mondal MMH, Alim MA, Moinuddin MA. Prevalence of lice infestation in humans in different socioeconomic status at Mymensingh in Bangladesh. Int J Bio Res 1: 13-17, 2010.

2. Amazonas PHM, Souza RBA, Mendes J, Moroni FT, Borges-Moroni R. Pediculose em crianças e jovens atendidos em orfanatos e ambulatório público de Manaus, AM, Brasil. Rev Patol Trop 44: 207-214, 2015.

3. Barbosa JV, Pinto ZT. Education a method of pediculosis control. In: Second Internat Congr on Phthiraptera, Queensland, Brisbane, 2002. 141 p.

4. Borges R, Mendes J. Epidemiological aspects of head lice in children attending day care centers, urban and rural schools in Uberlândia, Central Brazil. Mem Inst Oswaldo Cruz 97: 189-192, 2002.

5. Borges R, Junqueira J, Rodrigues RM, Mendes J. Prevalence and monthly distribution of head lice using two diagnostic procedures in several age groups in Uberlândia, State of Minas Gerais, Southeastern Brazil. Rev Soc Bras Med Trop 40: 1-3, 2007.

6. Borges-Moroni R, Mendes J, Justiniano SCB, Bindá AGL. Head lice infestation in children in daycare centers and schools of Manaus, Amazon, Brazil. Rev Patol Trop 40: 263-270, 2011.

7. Borges-Moroni R, Nunes SCB, Souza RBA, Mendes J, Moroni FT. O conhecimento de cuidadores e cabelereiros sobre aspectos epidemiológicos da pediculose da cabeça em Manaus, Amazonas, Brasil. Rev Sci Amazon 4: 60-65, 2015.

8. Catalá S, Junco L, Vaporaky R. Pediculus capitis infestation according to sex and social factors in Argentina. Rev Saúde Pública 39: 438-443, 2005.

9. Cazorla D, Ruiz A, Costa M. Estudio clínico-epidemiológico sobre pediculosis capitis en escolares de Coro, Estado Falcón, Venezuela. Invest Clín 48: 446-457, 2007.

10. Chouela E, Abeldano A, Cirigliano M, Ducard M, Neglia V, Forgia M, Colombo A. Head louse infestations: epidemiologic survey and treatment evaluation in Argentinian schoolchildren. Int $J$ Dermatol 36: 819-825, 1997.

11. Chunge RNA. Study of head lice among primary schoolchildren in Kenya. Trans R Soc Trop Med Hyg 80: 42-46, 1986.

12. Counahan M, Andrews R, Bütner P, Bymes G, Speare R. Head lice prevalence in primary schools in Victoria, Australia. J Ped Child Health 40: 616-619, 2004.

13. Courtiade C, Labrieze C, Fontan I, Taieb A, Maleville J. Pediculosis capitis: a questionnaire survey in 4 schools of the Bordeaux Academy 1990-1991. Ann Dermatol Venereol 120: 363-368, 1993.

14. Gabani FL, Maebara CML, Ferrari RAP. Pediculose nos centros de educação infantil: conhecimentos e práticas dos trabalhadores. Esc Anna Nery Rev Enfermag 14: 309-317, 2010.

15. Gutiérrez MM, González JW, Stefanazzi N, Serralunga G, Yañez L, Ferrero AA. Prevalence of Pediculus humanus capitis infestation among kindergarten children in Bahía Blanca city, Argentina. Parasitol Res 111: 1309-1313, 2012.

16. Heukelbach J, Haeff EV, Rump B, Wilcke T, Moura RCS, Feldmeier H. Parasitic skin diseases: health care-seeking in a slum in north-east Brazil. Trop Med Int Health 8: 368-373, 2003.

17. Heukelbach J, Pilger D, Oliveira FA, Khakban A, Ariza L, Feldmeier H. A highly efficacious pediculicide based on dimeticone: Randomized observer blinded comparative trial. J Infect Dis 8: 115, 2008. 
18. Kamiabi F, Nakhaei FH. Prevalence of pediculosis capitis and determination of risk factor in primary-school children in Kerman. East Mediterr Health J 11: 988-992, 2005.

19. Kokturk A, Baz K, Bugdayci R, Sasmaz T, Tursen U, Kaya TI, Ikizoglu G. The prevalence of pediculosis capitis in schoolchildren in Mersin Turkey. Int J Dermatol 42: 694-698, 2003.

20. Linardi PM, Barbosa J V. Anoplura. In: Neves DP, Melo AL, Linardi PM, Vitor RWA. Parasitologia Humana. Atheneu. São Paulo, 2016.

21. Linardi PM, De Maria M, Botelho JR, Cunha HC, Ferreira JB. Prevalence of nits and lice in samples of cut hair from floors of barbershops and beauty parlors in Belo Horizonte, Minas Gerais State, Brazil. Mem Inst Oswaldo Cruz 83: 471-474, 1988.

22. Linardi PM, De Maria M, Botelho JR, Cunha HC, Ferreira JB. Pediculose capitis: prevalência em escolares da rede municipal publica de Belo Horizonte, Minas Gerais, Brasil. Mem Inst Oswaldo Cruz 84: 327-331, 1989.

23. Linardi PM, De Maria M, Botelho JR, Hosken CI, Cunha HC. Alguns fatores epidemiológicos relativos a infestação humana por Pediculus capitis (Anoplura, Pediculidae) em Belo Horizonte, Minas Gerais, Brasil. Rev Bras Ent 39: 921-929, 1995.

24. MEC. Relatório educação para todos no Brasil 2000-2015. Versão preliminar 125 p. 2014. Available at: $\quad$ http://portal.mec.gov.br/index.php?option=15774-ept-relatorio-06062014\&Itemid=30192. Acessado em 08/2014.

25. Mirza A, Shamsi A. Head lice infestation. Innovait 3: 85-90, 2010.

26. Nazari M, Saidijam M. Pediculus capitis infestation according to sex and social factors in HamedanIran. Pak J Biol Sci 10: 3473-3475, 2007.

27. Nunes SCB, Moroni RB, Mendes J, Justiniano SCB, Moroni FT. Biologia e epidemiologia da pediculose da cabeça. Rev Sci Amazon 3: 85-92, 2014.

28. Nunes SCB, Borges-Moroni R, Mendes J, Justiniano SCB, Moroni FT. Head lice in hair samples from youths, adults and elderly in Manaus, Amazonas, State, Brazil. Rev Inst Med Trop São Paulo 57: 239-244, 2015.

29. Pagotti RE, Santos VP, Bisson GS, Santos MJSFL, Ferreira BR. Avaliação de um programa para controle de pediculose em uma escola. Sau \& Transf Soc 3: 76-82, 2012.

30. Piquero-Casals V, Pérez M, Quintero I, Ramirez B, Piquero-Martín J. Epidemiología de la pediculosis capitis en escolares del Distrito sanitário N 3 em Caracas, Venezuela. Dermatol Venez 42: 19-22, 2004.

31. Raheem TAAEl, Sherbiny NAEl, Elgameel A, Sayed GAEl, Moustafa N, Shahen S. Epidemiological comparative study of pediculosis capitis among primary school children in Fayoum and Minofiya Governorates, Egypt. J Community Health. Springer Science Business Media, New York, 2014.

32. Reinhard KJ, Buikstra J. Louse infestation of the Chiribaya culture, southern Peru: variation in prevalence by age and sex. Mem Inst Oswaldo Cruz 98: 173-179, 2003.

33. Saddozai S, Kakarsulemankhel JK. Infestation of head lice, Pediculus humanus capitis, in school children at Quetta City and its suburban areas Pakistan. PakJ Zool 40: 45-52, 2008.

34. Speare R, Buettner PG. Head lice in pupils of a primary school in Australia and implications for control. Inter J Dermatol 38: 285-290, 1999.

35. Toloza A, Vassena C, Gallardo A, Audino PG, Picollo I. Epidemiology of pediculosis capitis in elementar schools of Buenos Aires, Argentina. Centro de Investigaciones de Plagas e Insecticidas. Parasitol Res 104: 1295-1298, 2009.

36. Triplehorm CA, Jonnson NF. Estudo dos insetos. $7^{\mathrm{a}}$ ed. Cengage Learning, 66. São Paulo, 2011. pp. 359-366.

37. Zar JH. Bioestatistical Analysis. 4.ed. New Jersey: Prentice Hall, 1999. pp. 210-214. 